\title{
Gender Analysis of the Tuna Value Chain's Purchasing Stage in the South Central Provinces of Vietnam-Case Study of Binh Dinh Province
}

\author{
Nguyen Dang Hoang Thu ${ }^{1,2}$, Rachel Sundar Raj ${ }^{2}$, Cao Le Quyen ${ }^{3}$, Le Thi Minh Hang ${ }^{4}$, Nang Thu Tran Thi ${ }^{5}$ \\ \& Philippe Lebailly ${ }^{2}$ \\ ${ }^{1}$ Faculty of Project Management, The University of Danang - University of Science and Technology, Da Nang, \\ Vietnam \\ ${ }^{2}$ Economy and Rural Development Department, Faculty of Gembloux Agro-Bio Tech, Liege University, \\ Gembloux, Belgium \\ ${ }^{3}$ Vietnam Institute of Fisheries Economics and Planning, Ha Noi, Vietnam \\ ${ }^{4}$ Faculty of Business Administration Management, The University of Danang - University of Economics, Da \\ Nang, Vietnam \\ ${ }^{5}$ Faculty of Fishery, Vietnam National University of Agriculture, Ha Noi, Vietnam \\ Correspondence: Nguyen Dang Hoang Thu, Faculty of Project Management, The University of Danang - \\ University of Science and Technology, Da Nang, Vietnam. Tel: 84-905-620-897. E-mail: ndhthu@ dut.udn.vn
}

Received: November 3, 2020

Accepted: December 22, 2020

Online Published: December 30, 2020

doi:10.5539/ass.v17n1p1

URL: https://doi.org/10.5539/ass.v17n1p1

\begin{abstract}
This study aims to identify the gender disparities between men and women as purchasing actors in the tuna value chain in South Central provinces, thereby suggesting gender-sensitive policies towards gender equity, women's empowerment, and sustainable tuna fisheries management. The study was conducted with the aid of a set of structured questionnaires executed through personal interview surveys. Tam Quan and Quy Nhon fishing ports in Binh Dinh province were chosen as study sites for conducting gender analysis at the tuna value chain's purchasing stage in the South Central provinces of Vietnam. Forty respondents were directly interviewed at their home or at the fishing ports in Binh Dinh province in May 2020, of which are ten middlemen and nine middlewomen purchasing yellowfin and bigeye tunas at Tam Quan fishing port; and twelve middlewomen and nine female traders purchasing skipjack tuna at Quy Nhon fishing port. This study used gender analysis tools such as the Harvard, Moser, and the USAID's six gender dimensions to identify gender differences between men and women in the tuna purchasing stage in productive, reproductive, and community managing roles. Some policy recommendations for improving gender equity, women's empowerment, and sustainable tuna fisheries management were proposed, including (i) describe the importance of women's reproductive role in gender-responsive strategies; (ii) establish tuna trading management board at the fishing port to collect information on the needs, issues, and interests of purchasing actors; (iii) organize training courses on tuna business and management skills at the fishing ports during the low season for the full participation of middle-actors, especially women; (iv) provide access to savings, credit, and microfinance for female traders to create opportunities for expanding their business; (v) improve facilities at the fishing ports to increase the overall well-being of the fish trading communities; (vi) introduce alternative job opportunities for laborers in the tuna purchasing stage during the low season; (vii) support laborers trading yellowfin and bigeye tuna in seeking other ways to make a living due to the depletion of these tuna resources.
\end{abstract}

Keywords: tuna value chain, gender analysis, middle-actors, gender equity, women's empowerment, sustainable tuna fisheries management, Vietnam

\section{Introduction}

Women play a significant role in world fisheries (Bennett, 2005), but traditionally, fisheries have taken for granted to men (Williams, 2008; Fröcklin, Castro, Lindström, \& Lindström, 2013). Actually, in developing countries, women living in coastal areas, with various roles, participate in the small-scale fisheries sector as gleaners, fishers, traders, processors, and marketers of fisheries products (Weeratunge \& Snyder, 2009; FAO, 2011; FAO, 2015). Although women participate in fishing, processing, and selling, many of these roles have 
been overlooked, under-acknowledged, and almost invisible in fisheries management and policy development (Chapman, 1987; Harper et al., 2017). Also, there exists gender inequality in the fisheries sector (Koralagama, Gupta, \& Pouw, 2017). In particular, women are restricted on resource access (Hauzer, Dearden, \& Murray, 2013; Thorpe et al., 2014) and on decision making (Choo et al., 2008; Medard, 2012; Calhoun, Conway, \& Russell, 2016), and even suffer from discrimination based on identity (Weeratunge et al., 2014; Vervaele, 2014). Moreover, (Weeratunge, Snyder, \& Sze, 2010) asserted that this gender inequality affects women's livelihood and their entire households since women are also related to reproductive work.

Although women have an important role in the fisheries sector, their social roles have often remained invisible to researchers and policy makers (Bennett, 2005). Besides, gender aspects are often ignored in fisheries policy and research (Diamond, Squillante, \& Hale, 2003; Harper et al., 2013). Lack of understanding about the role of women in the fisheries sector as well as attention to the gender dimension of fisheries management can lead to failure of policy interventions, hence achieving the target of creating sustainable livelihoods at the community level is impossible (Bennett, 2005). Furthermore, (Bennett, 2005) argued that policy interventions that address gender roles in the development process help strengthen institutional capacity in coastal artisanal communities, which would have the greatest overall impact. Also, the European Institute for Gender Equality (EIGE, 2015) exhibited that doing a gender analysis in the fisheries sector provides the necessary data and information in integrating a gender perspective into policies, programs, and projects. This supports the development of interventions in order to eradicate gender inequalities and meet women's and men's different needs in fishing communities (EIGE, 2015). Thus, it can be said that it is meaningful to include gender aspects in research and policy in the fisheries sector. However, there has been few research on gender analysis in Vietnam's fishing community so far, except for the two studies on gender analysis in the shrimp value chain, including (Veliu, Gessese, Ragasa, \& Okali, 2009) and (Oxfam, 2016).

To fill the research gap, we conducted a gender analysis at the tuna value chain's purchasing stage of in Binh Dinh province, one of three South Central Provinces of Vietnam. The objectives of this study were not only to identify the different roles of men and women as purchasing actors but also to acknowledge their needs and challenges in the tuna value chain in the South Central Provinces of Vietnam, thereby suggesting gender-sensitive policies to aim at a fairer and more sustainable management in the tuna fisheries community. In particular, our study aims to:

- Provide empirical evidence for gender analysis in the tuna fisheries community by analyzing gender disparities between men and women in the tuna purchasing stage and identifying the specific roles of women as middle-persons and traders in the tuna value chain;

- Suggest recommendations for gender-sensitive policies, research, and actions to improve gender equity and women empowerment in the tuna fisheries community and promote sustainable tuna fisheries management in the region.

This paper is organized as follows. Section 2 provides a short review of related work on gender analysis of tuna value chains as a background for this research. Section 3 describes the method of this study, and the results are given in Section 4. Finally, discussions and conclusions are presented in Section 5.

\section{Related Work on Gender Analysis in Tuna Value Chains}

On the gender analysis of tuna value chains, most researchers studied about women's roles in tuna fisheries and gender differentials between men and women along the chain. Some case studies in this research direction are briefly summarized as below.

Firstly, (Tuara, 2006) established what is known on the involvement of women in the tuna fishery in the Pacific Islands and the impacts of tuna fisheries on women. As a review, this study looked at national, regional, and international articles, documents, field reports, and books written on women in development, gender in development, women in fisheries, and the assessment, management, and development of Pacific Islands tuna fisheries. In addition, it showed that most women were found in processing for small-scale and commercial fisheries and marketing for the domestic market, while men were found in capturing and commercial marketing areas. The study also identified some positive and negative effects of fisheries on women and suggested some actions to improve gender equity.

Secondly, (Kruijssen et al., 2013) put a gender lens on value chain analysis to understand why men and women fulfill certain roles at every level in marine resource value chains, especially the tuna value chain in the Solomon Islands. A gender analysis of marine resource value chains was done to help identify key entry points for equitable improvement of the livelihoods of those participating in the chains. Using the gender division labor and 
livelihood approaches, this study showed the differences in men's and women's gender-specific roles in marine resource value chains and other livelihood activities in two communities in the Solomon Islands. These disparities lead to unfair outcomes and opportunities for men and women, affecting their livelihood security and well-being. Some key recommendations were suggested, including: (i) In order to assess and intervene in marine resource-based livelihoods, it is necessary to identify the gender disparities and to explain the main reasons for these differences; (ii) To improve the equity of gender and decision-making, it is essential to build capacity and knowledge of women for contributing to decision-making processes; (iii) Several potential entry points for upgrading marine resource value chains were proposed such as exploration of different models of coordination and collective effort among fishers and gleaners, especially for women, and provision of training and awareness on processing options to improve fish preservation.

Thirdly, (Barclay, Payne, Mauli, \& Krushelnytska, 2015) examines women's involvement in two supply chains in the fisheries sector of the Solomon Islands - tuna fisheries and coastal fisheries. It used the fish chain as a conceptual framework to analyze gender aspects of the fisheries supply chain. Some gender issues were found in the tuna fisheries and coastal fisheries value chains. The study also suggested some recommendations for improving the information and data on gender analysis to better address women's inclusion in fisheries, thereby enhancing this sector's social benefits and outcomes in the Solomon Islands.

Fourthly, (Wessels, 2017) provided an analysis of the roles of women playing in pole-and-line and handline tuna supply chains in Maldives. The fish chain was also used as a means to investigate gender aspects of the fisheries supply chain. Besides, this study proposed some factors influencing the roles of women in the community, such as improving the quality of life and providing access to education and employment for women, and the impact of access to technology, social network, and mass media on increasing the status of women and opportunities offered to women in Maldives.

Furthermore, (O'Neill, Asare, \& Aheto, 2018) emphasized the significant roles of middlewomen in the Ghanaian tuna industry. Their key roles to the global seafood industry at the local scale were exhibited by financing industrial tuna fleets that supplies tuna for major international export companies. Their participation facilitates the operation of large seafood corporations.

Lastly, (USAID, 2018) used the USAID's gender dimensions framework with its six domains, including access to assets; knowledge, beliefs and perceptions; practices and participation; time and space; legal rights and status; power and decision making to capture the gender differentials along the tuna value chain and across different types of fishing. The project included both small-scale tuna (municipal fisheries) and large-scale tuna (hand line and purse seine fisheries) in Philippine and Indonesia.

Gender analysis of the tuna value chain has been conducted in tuna-fishing countries such as Philippine, Indonesia, Solomon Islands, Pacific Islands, Maldives, and Ghana. Meanwhile, there has been no research on gender analysis of the Vietnamese tuna value chain, although Vietnam is one of the countries with developed tuna fisheries in Southeast Asia. Therefore, conducting a gender analysis on the tuna value chain's purchasing stage in Southern Central Provinces of Vietnam fills the research gaps. We only carried out the gender analysis on the tuna purchasing stage due to our limited budget and time constraints. Furthermore, purchasing actors play a key role in the tuna supply chain in Vietnam in the context of small-scale fisheries since they act as local purchasing agents for the processing plants and provide loans and input for fishers. Thus, they have a certain influence on fishers' changing practice (e.g., for e-logbook and traceability systems) and help processors develop and operate a better traceability system if incentives were provided (e.g., premium prices and a more stable price for traceability products) (USAID, 2020). Also, men and women are involved in tuna procurement, whereas only men are involved in tuna exploitation. Therefore, this study aims to identify the different roles of men and women as purchasing actors of the tuna value chain as well as acknowledge their needs and challenges in the tuna fisheries communities in the South Central Provinces of Vietnam, thereby proposing gender-sensitive policies toward more equitable and sustainable tuna fisheries management in these communities.

Referring to gender analysis methods used in the fisheries sector, firstly, (Overa, 1993; Walker, 2001; Walker, 2002; Silva, 2011) use gender division of labor approach to identify the role of women in the fisheries sector. Also, (Weeratunge, 2012) use a conceptual framework that combines with the social relations approach (Kabeer 1995; Kabeer, 1996; Kabeer, 1999) and social well-being approach (McGregor, Camfield, \& Woodcock, 2009) to analyze gender roles, relations, assets, capabilities, and decision-making within individuals, households, and communities, as well as in the wider institutional context of the market and state in the aquatic agricultural systems of five countries including Cambodia, Zambia, Bangladesh, Philippines, and the Solomon Islands. Furthermore, (Hillenbrand, Lakzadeh, Sokhoin, \& Talukder, 2014) uses the Social Relations approach to assess 
the impact of a gender lens on women's empowerment and better understand gender relations in Cambodia. Finally, (USAID, 2018) used a gender-responsive value chain analysis which is combined between USAID's six gender dimensions and Harvard and Moser approaches to identify gender differences in activity profiles and three roles of men and women in production, reproduction, and community on tuna value chains in the Philippines and Indonesia. Our study also employs six gender dimensions of USAID and Harvard and Moser gender analysis tools to analyze gender disparities between men and women in the tuna purchasing stage and identify women's specific roles as middle-persons and traders in the tuna value chain in Vietnam.

\section{Methodology}

This section presents the study area, study design, and analytical method. Firstly, the purchasing sites involved in the study are described in details. Then, the study design consists of secondary data collection, key informant interviews, and personal interview surveys, which provide qualitative and quantitative data for gender analysis. Lastly, an analytical method based on the Harvard, Moser, and USAID's six gender dimensions is given.

\subsection{Study Area}

This study was undertaken in Binh Dinh province in May 2020. Binh Dinh has the largest tuna production in Vietnam, and is one of the three provinces chosen for carrying out the research of (Thu, Quyen, Hang, Tran, \& Lebailly, 2020). During this period, personal interview surveys were conducted with middle-persons and traders purchasing tuna at Tam Quan and Quy Nhon fishing ports.

Purchasing actors consist of middle-persons and traders, who play a significant role in Binh Dinh province's tuna supply chain. Traders buy tunas directly from fishing vessels, then sell most of them to middle-persons or processors and the remainder to domestic markets. Meanwhile, middle-persons buy tuna directly from fishers or traders and act as local purchasing agents for processors. Also, these middle-actors provide finance and inputs for fishers such as gasoline, oil, ice; thus having a certain influence on fishers (Thu, Quyen, Hang, Tran, \& Lebailly, 2020) and (USAID, 2020). Middle-persons often have capital and business scales more considerable than those of traders, hence, the former provide finance and input for more vessels than the latter.

Binh Dinh is a province in the South Central Coast of Vietnam with a total natural area of 6,025 squared kilometers and a population of about 1.6 million people. It has a coastline of over 134 kilometers. Binh Dinh has offshore fisheries, among which the tuna fishing is the most developed in Vietnam and mostly concentrated in Hoai Nhon district and Quy Nhon city. It currently has three large fishing ports, including Quy Nhon, De Gi, and Tam Quan ports (Binh Dinh Province People's Committee, 2018). Figure 1 describes the map of Binh Dinh province.

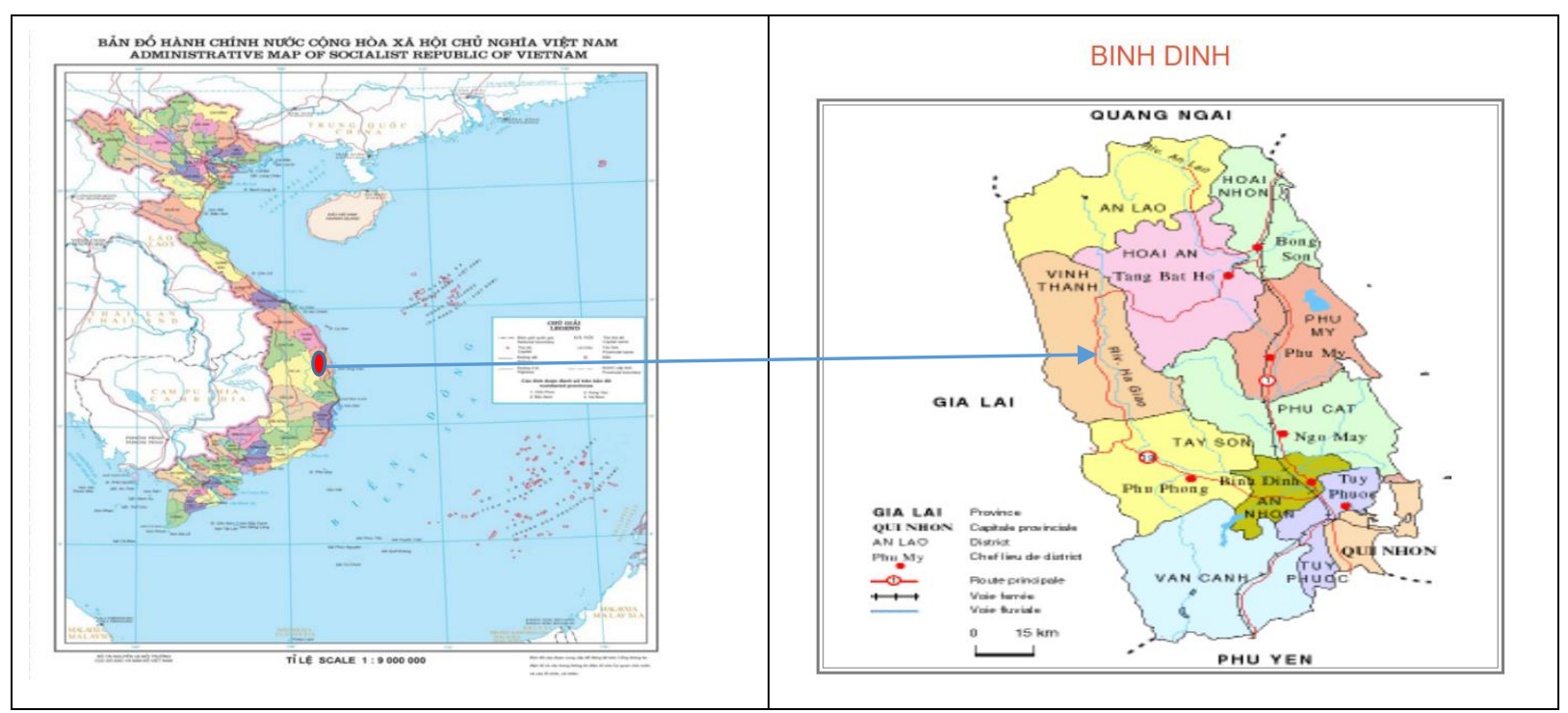

Figure 1. Map of Binh Dinh Province of Vietnam.

Source: (Binh Dinh Province People's Committee, 2018)

Our research focused on Tam Quan and Quy Nhon ports as specific sites to conduct gender analysis of the tuna value chain's purchasing stage. Quy Nhon port is located in Hai Cang ward, Quy Nhon city, Binh Dinh province. It is considered the largest wholesale market for skipjack tuna, where most middle-persons and traders are women. This fishing port's peak operating time is from $0 \mathrm{am}$ to $8 \mathrm{am}$, and the activities of purchasing skipjack 
tuna take place here all year-round. Meanwhile, Tam Quan port lies in Hoai Nhon district, Binh Dinh province, where many yellowfin and bigeye tuna fishing vessels land. It is recognized as the largest marketplace for purchasing yellowfin tuna and bigeye tuna in the province, where both men and women work as middle-persons or traders. Its peak operating time is from 7 am to $5 \mathrm{pm}$, and the trading activities only take place here between the $7^{\text {th }}$ and the $23^{\text {rd }}$ of every month in the lunar calendar.

Binh Dinh has two tuna value chains, which are (i) skipjack tuna value chain, and (ii) yellowfin and bigeye tuna value chain. For the former, tunas are caught by purse seine and gillnet fisheries. Once fishing vessels have landed at Quy Nhon port, shipowners report the output of caught tuna to the managers at the port. Skipjack tunas are then unloaded and sold to middle-actors, which include middle-persons and traders. After that, only a small number of fresher and finer tunas are sold at the port with a higher price for domestic markets, whereas a large proportion of the tunas are sold to processing enterprises to produce canned tuna serving for export markets. The processors determine purchasing prices, and purchasing actors receive commissions based on the buying volume. For the latter, tunas are caught by longline/hand-line fisheries, then landed at Tam Quan port. Similar to the former, middle-actors mostly act as local purchasing agents for processing enterprises and receive commissions. Most of caught yellowfin and bigeye tunas are transported to processors in order to process them into frozen tuna fillets catering for export markets. Only a tiny proportion of the tunas is processed into tuna fillets dedicated to hotels and restaurants in domestic markets (Thu, Quyen, Hang, Tran, \& Lebailly, 2020).

\subsection{Research Design}

Gender analysis at the tuna purchasing stage is based on the qualitative data provided by secondary data collection, key informant interviews (KII), site visits, and the quantitative data taken from personal interviews.

\subsubsection{Secondary Data Collection}

The secondary data was collected from various sources, including the Provincial Department of Fisheries in Binh Dinh, Management Boards of Quy Nhon and Tam Quan fishing ports, and studies such as (Thu, Quyen, Hang, Tran, \& Lebailly, 2020) and (USAID, 2020). This data provides the inputs to a desk review on the tuna value chain in Binh Dinh and insights on purchasing actors' tuna business. The literature on gender analysis in the fisheries sector in other countries was reviewed during the research process to finalize the research instruments and tools.

\subsubsection{Key Informant Interviews}

Key Informant Interviews were conducted with four persons including two employees of Binh Dinh's Department of Fisheries and two directors of the management board of Quy Nhon and Tam Quan ports. These interviews aim to provide better understanding about the overall enabling environment for gender equality in fishing communities in the local area, especially the different roles that men and women play in the tuna purchase, participation, decision-making, marketing, and management in the tuna fisheries community. During the interview process, the fishing ports' directors also provided us with the contacts of middle-actors, who purchase tunas, for facilitating face-to-face interviews.

\subsubsection{Personal Interview Surveys}

Personal interview surveys were conducted with nineteen middle-persons (including ten middlemen and nine middlewomen) who do purchase of yellowfin and bigeye tuna at Tam Quan port, and twelve middle-persons and nine traders (all are women) who mainly buy skipjack tuna at Quy Nhon port. All interviewees are either the directors of tuna purchasing companies or the owners who manage their tuna purchasing activities at the ports. Out of the ten middlemen interviewed at Tam Quan port, only two directly manage the tuna purchase at the port. The remaining middlemen are the owners of tuna purchasing enterprises, who are responsible for managing transactions with processors as well as gas stations and ice storage, while their wives, even though are not legal owners, take charge in managing the tuna purchase at the port.

A set of structured questionnaires were developed to facilitate data collection relating to middle-persons and traders in Binh Dinh. The Harvard, Moser, and USAID's six gender analysis domains were used to build the questionnaires. The information content to collect in the designed questionnaires includes general information of the interviewees, their tuna businesses, and USAID's six gender analysis domains related to these interviewees, which include: practice and participation; knowledge, beliefs, and perceptions; legal rights and status; power and decision making; time and space (Sundar Raj, 2020).

The survey instruments were designed to capture the productive, reproductive, and community roles of men and women as middle-persons and traders at the tuna purchasing stage in Binh Dinh. Multiple-choice answers were developed for each question, with an added option of "Others, please specify" to capture answers that are often 
unpredictable in the questionnaire development process. Besides, some open-ended questions were designed to understand the respondent's opinions on related issues. We translated the structured questionnaires into the local language, and upon completion of the interview, the questions and answers back-translated to English to ensure that nothing was lost in the process of translation. The average interview lasted from thirty to forty minutes and took place at the fishing port or the respondents' home. All interviews were recorded for further analysis.

\subsection{Analytical Method}

Gender analysis at the tuna purchasing stage in Binh Dinh aims to identify gender differences in the roles, tasks, opportunities, and constraints of men and women as middle-persons or traders in productive, reproductive, and community managing roles.

Gender analysis tools such as Harvard, Moser, and USAID's six gender dimensions were employed as frameworks for this research. The Harvard Analytical framework (March, Smyth, \& Mukhopadhyay, 1999) also known as the Gender Roles Framework, was used to analyze men's and women's productive and reproductive roles. Also, the Moser framework (Moser, 1993) was applied to assess community roles, which are classified into community managing activities and community politics. Using gender analysis tools such as the Harvard and Moser approaches is necessary to identify gender differentials in activity profiles and generates strategic and practical gender needs, a significant step in developing interventions that integrate and mainstream gender concerns. Additionally, this analysis was also based on USAID's six gender dimensions (USAID, 2012) to assess gender differentials in access to assets, knowledge and perceptions, practices and participation, time and space, legal rights and status, and power and decision-making. Table 1 presents USAID's six gender dimensions and their associated gender issues.

\subsection{Data Analysis}

After interviewing forty interviewees at Quy Nhon and Tam Quan ports, we created the questionnaires on Google Forms due to its facilitation for data analysis. The paper answers were manually encoded in the online survey, and then a data file in Microsoft Excel was automatically generated by Google Form. Data were analyzed in this file, and then the descriptive statistics and comparison between men and women were performed with $\mathrm{R}$ software. There are only forty people in the sample, and the data are non-parametric (the Shapiro tests proved that also), thus, the Wilcoxon rank-sum test was conducted instead of t-text, and the function wilcox_test were used to compare the difference between men and women. As more categories were compared, Kruskal-Wallis tests (Kruskal.test) were used, followed by Dunn tests (dunn_test). In this study, a five percent level of significance was used. The occurrence of relevant words among responses was observed and counted for open-ended questions. Finally, field notes, experiences from site visits, ocular inspection, and finding from secondary data enriched for doing gender analysis at the tuna purchasing stage (Sundar Raj, 2020).

Table 1. The six domains and their associated key issues

\begin{tabular}{|c|c|}
\hline Domain & Key Issues \\
\hline Access to assets & Who has access to which particular assets? What constraints do they face? \\
\hline $\begin{array}{l}\text { Knowledge, beliefs, } \\
\text { perceptions }\end{array}$ & Who knows what? What beliefs and perceptions shape gender identities and norm? \\
\hline $\begin{array}{l}\text { Practices and } \\
\text { participation }\end{array}$ & $\begin{array}{l}\text { Who does what? What are the gender roles and responsibilities that dictate the activities in which } \\
\text { men and women participate? How do men and women engage in development activities? }\end{array}$ \\
\hline Time and space & How do men and women spend their time, as well as where and when? \\
\hline Legal rights and status & How are women and men regarded and treated by customary and formal legal codes? \\
\hline $\begin{array}{c}\text { Power and } \\
\text { decision-making }\end{array}$ & $\begin{array}{l}\text { Who has control over the power to make decisions about one's body, household, community } \\
\text { municipality and state? Are such decisions made freely? }\end{array}$ \\
\hline
\end{tabular}

Source: (USAID, 2012)

\section{Results}

\subsection{Characteristics of Purchasing Actors and General Work Situation}

The field survey results showed that the skipjack tuna trade at Quy Nhon port was traditionally associated with women (one hundred percent of total middle-persons and traders were women). In comparison, the purchase of yellowfin and bigeye tuna at Tam Quan port was taken by both men and women, which occupied fifty-three percent and forty-seven percent, respectively. At Qui Nhon port, the respondents' mean age was forty-eight years old for middlewomen, and forty-four years old for female traders. Meanwhile, the respondents' average age was forty-eight years old for middlemen, and for fifty years old for middlewomen at Tam Quan port. All interviewees were married, except for one single female trader. The average household size was six, and wives tend to be 
younger than husbands.

The educational level among interviewed female traders was generally quite low since their highest one was only up to the middle school. Meantime, middle-persons had a higher education level among which four persons attained the university level. The middlemen's education level was higher than that of middlewomen. For example, there were six middlemen and only one middlewoman completing high school.

In terms of tuna purchasing experience, women had a longer average time in business than men, but the difference is non-significant (Wilcoxon, $\mathrm{p}=0.5283$ ). The average business time was $12 \pm 10.6$ years for women and $9.95 \pm 10.4$. years for men. However, men tend to have a promotion in work faster than women with $3.5 \pm$ 1.84 years and $4.28 \pm 3.65$ years, respectively, but the difference is not significant (Wilcoxon, $\mathrm{p}=0.6887$ ) . Regarding reasons for career choice, tradition and relation have been mentioned many times and equally for both men and women. Most middle-persons and traders said that their family has been in the tuna business for years, so they have good relationships with processors and fishers. Also, the stability and good income were factors for purchasing actors to pursue their job for a long time.

In the tuna business, most women were involved in the purchase of skipjack tuna, whereas both men and women were related to the yellowfin and bigeye tuna trade. There were no male respondents in the skipjack business since this business requires a lot of time, meticulousness, and diligence which are dominant characteristics among female partners. Skipjack tuna is a much smaller size than yellowfin and bigeye tuna, so it takes more time and effort to classify according to size and quality. A large amount of skipjack tuna is sold to processors for export, whereas the remaining part, beautiful tunas, are sold to wholesalers at the fishing port from 0 am to 8 am, a hard time for purchasing actors. Meanwhile, yellowfin tuna and bigeye tuna are mainly sold to processing companies from 7 am to $5 \mathrm{pm}$, a more pleasant time than the skipjack tuna trade.

Regarding the quantity of yellowfin and bigeye tuna traded in an average month, the middlewomen dealt with larger quantities than middlemen, however, the difference is not significant (Dunn, $\mathrm{p}=0.691$ ). Regardless of the species of tuna and the profession, women dealt with significantly larger quantities than men (Wilcoxon, $\mathrm{p}=$ $0.045)$ with average means of $336,500 \pm 347,471(\mathrm{~kg} / \mathrm{month})$ and $165,500 \pm 136,615$ (kg/month), respectively. Table 2 presents price of kilogram of tuna, and the monthly quantity of tuna traded in Binh Dinh province according to gender and tuna species.

Table 2. Price of Kilogram of Tuna, Monthly Quantity of Tuna Traded according to Gender and Tuna Species

\begin{tabular}{|c|c|c|c|c|}
\hline \multicolumn{2}{|c|}{ Tuna Species } & Yellowfin \& Bigeye Tuna & \multicolumn{2}{|c|}{ Skipjack Tuna } \\
\hline \multicolumn{5}{|c|}{ Price of a kilogram of fresh tuna in May, 2020 (VND) } \\
\hline \multirow{3}{*}{\multicolumn{2}{|c|}{$\begin{array}{c}\text { Men } \\
\text { Women }\end{array}$}} & Middle-person & Middle-person & Trader \\
\hline & & $83,700 \pm 823$ & & \\
\hline & & $83,222 \pm 1,563$ & $34,583 \pm 669$ & $34,222 \pm 441$ \\
\hline \multicolumn{5}{|c|}{ Quantity of tuna traded per month (kg/month) } \\
\hline & & Middle-person & Middle-person & Trader \\
\hline \multirow{2}{*}{ Low month } & Men & $126,000 \pm 103,409$ & & \\
\hline & Women & $241,111 \pm 163,435$ & $564,167 \pm 444,843$ & $85,556 \pm 30,766$ \\
\hline \multirow{2}{*}{ Peak month } & Men & $205,000 \pm 169,984$ & & \\
\hline & Women & $314,444 \pm 215,355$ & $757,500 \pm 595,622$ & $171,111 \pm 61,531$ \\
\hline \multirow{2}{*}{ Average month } & Men & $165,500 \pm 103,409$ & & \\
\hline & Women & $167,778 \pm 112,891$ & $379,167 \pm 297,305$ & $128,333 \pm 46,149$ \\
\hline
\end{tabular}

Source: (Sundar Raj, 2020) Note: VND: Vietnamese dong

In terms of monthly average profit, middlewomen had significantly higher profits than that of female traders in the skipjack tuna trade (Dunn, $\mathrm{p}=0.0328$ ), whereas middlewomen had a slightly higher profit than middlemen in the yellowfin and bigeye tuna purchase, yet the difference is neglibible (Dunn, $\mathrm{p}=0.485$ ). The daily capital was used more or less constant for men and women. For example, the money generated was always reinvested in a "special pot" only used for tuna trade. The money left after subtracting loading and unloading costs, ice and transportation costs, and after reinvesting in the pot, was considered as income.

\subsection{Six Domains of Gender Analysis}

\subsubsection{Access to Assets}

In addition to tuna purchase, middle-persons and traders are also responsible for financial sponsorship and provide oil or ice for shipowners catching tuna. The results showed that each middle-actor provided finance for 
at least ten tuna fishing vessels, and the average amount invested for a vessel was from three hundred to three hundred and fifty million Vietnamese dong. In terms of yellowfin and bigeye tuna's chain, middlewomen financed more vessels than middlemen, however, the difference is not significant (Wilcoxon, $p=1$ ). Meanwhile, the number of tuna vessels financed by female traders was less than five times that financed by middlewomen (Dunn, $\mathrm{p}=0.0151$ ). Figure 2 shows the average number of tuna vessels financed by purchasing actors according to gender and profession.

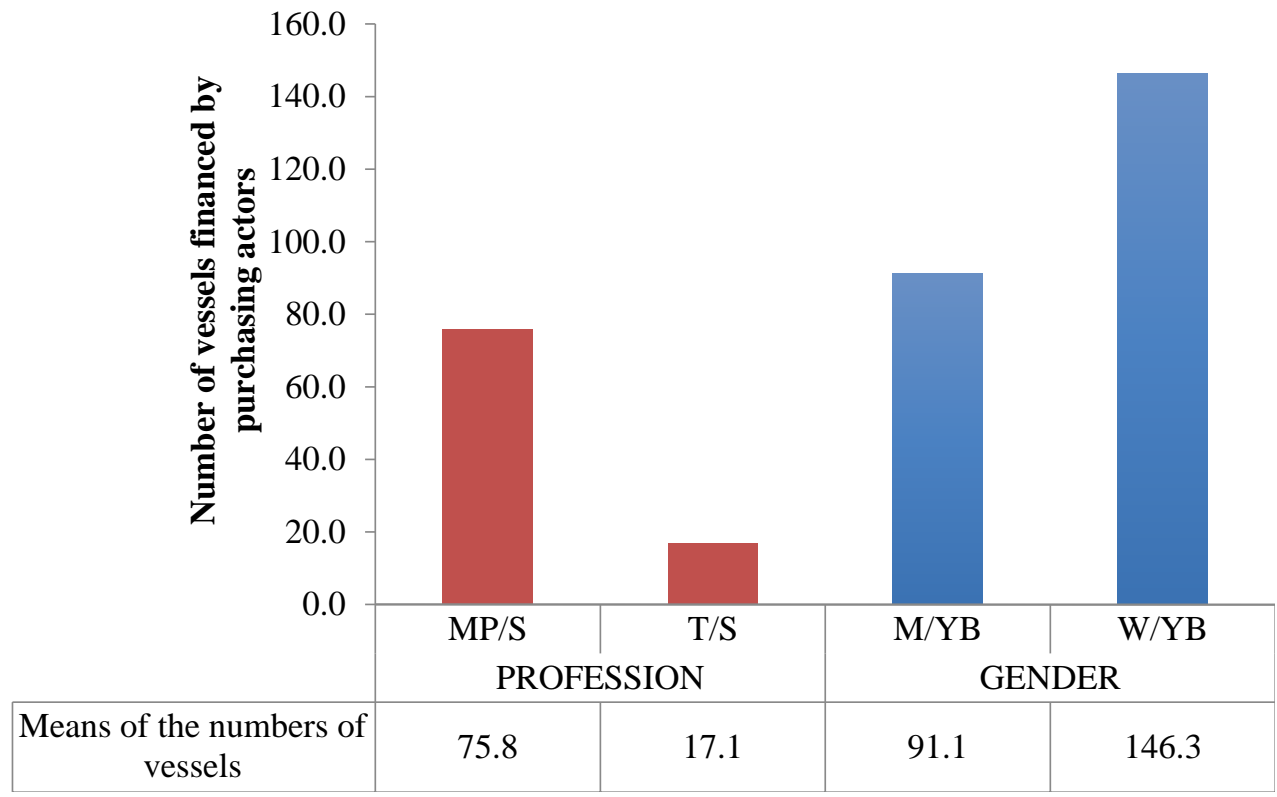

Figure 2. Number of tuna vessels financed by purchasing actors according to profession and gender Source: (Sundar Raj, 2020)

Note. MP/S: Middle Person purchasing skipjack tuna; T/S: Trader purchasing skipjack tuna; M/YB: Men (Middlemen) purchasing yellowfin tuna and bigeye tuna; W/YB: Women (Middlewomen) purchasing yellowfin tuna and bigeye tuna.

Most purchasing actors who provide inputs for fishers catching tuna were the owners of ice factories and petrol stations. Regarding the yellowfin and bigeye tuna trade, the percentage of middlemen owning one petrol station was significantly higher than that of middlewomen with eighty-eight percent and forty percent, respectively. In the skipjack tuna trade, the percentage of middlewomen owning a petrol station was very high, with sixty-four percent, whereas that of female traders was quite low with only twenty percent. All middlewomen in the sample responded that although they owned ice factories and petrol stations, their husbands had a decisive voice on the matters on the use, maintenance, and operations of ice factories and petrol stations. Most purchasing agents also had some necessary and additional items related to the tuna trading activities such as cell phones, motorbikes, freezers, refrigerators, calculators, knives, scissors, tables, baskets, and bags.

The purchasing actors are financially independent or borrow money from formal financing institutions to raise capital in the tuna business operations and their working capital requirements. The survey showed that middlewomen and middlemen tend to borrow money from banks, whereas female traders rely on self-financing. The respondents explained that middle-persons need more working capital to operate their tuna business operations, such as a large amount of money to finance many vessels, buy tuna from fishers, and invest in ice factories and petrol stations. Furthermore, middle-persons are often very rich and have more collateral than traders, hence, they borrow money from the bank more easily than traders. Meanwhile, female traders often have a small business scale and do not have much collateral, so they relied heavily on self-financing. The results also indicated that middlewomen tend to borrow from banks more than middlemen. This can be explained by the fact that middlewomen often owned larger tuna purchasing companies than middlemen. All respondents contended that their purchasers, such as processing companies, restaurasnt owners, etc., did not provide them with any sources of financing, and they did not have access to financing assistance/support from the government. Figure 3 depicts number of respondents using sources of financement of the business according to gender, profession, and species of tuna. 


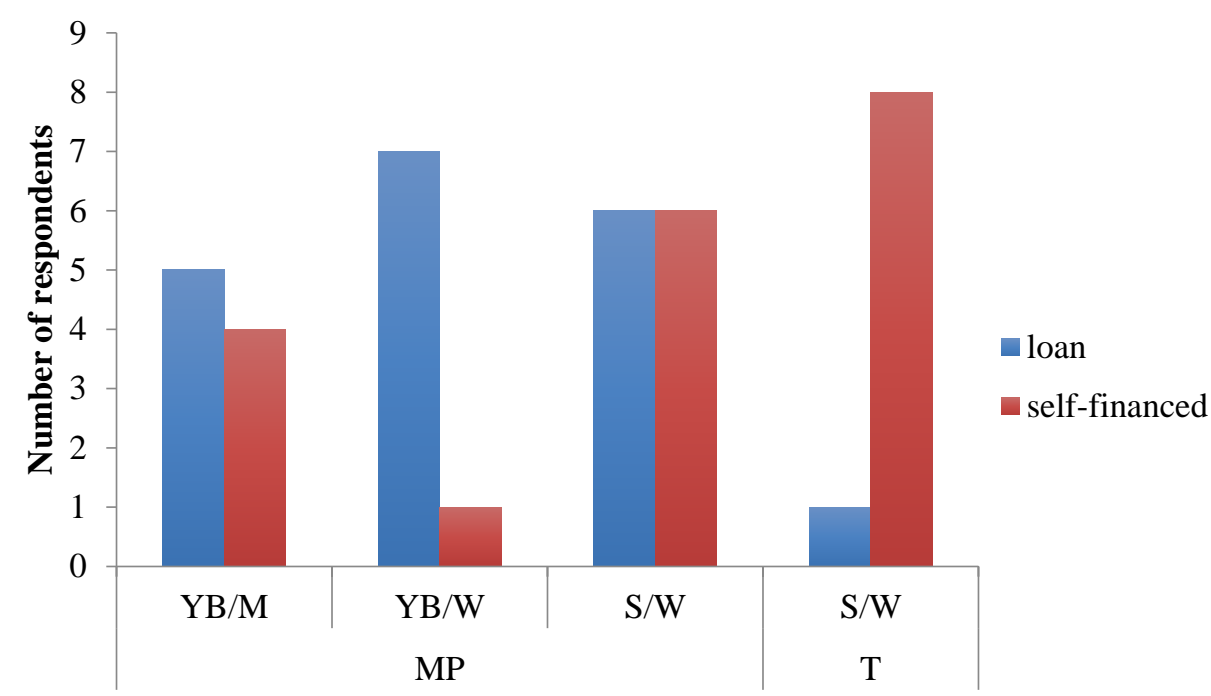

Gender, profession and species of tuna

Figure 3. Number of respondents use sources of financement of the business according to gender, profession, and species of tunaSource: (Sundar Raj, 2020)

Note. MP: Middle Person, T: Trader, YB/M: Men purchasing yellowfin and bigeye tuna, YB/W: Women purchasing yellowfin and bigeye tuna, S/W: Women purchasing skipjack tuna.

Both men and women generally purchased tuna at the same place at the fishing port every day, which was due to familiarity in terms of not only the place of business but also other suppliers (fishers) and customers (processing companies, restaurant owners, wholesalers, etc.). Men only involved in purchasing yellowfin and bigeye tuna, so their main customers were processors, exporters, and restaurant owners. Meanwhile, women participated in purchasing all tuna species, so their customers were more diverse, including processors, exporters, restaurant owners, wholesalers, retailers, etc. Besides, middlemen's customers were mainly men, while both men and women were customers of middlewomen and female traders. Men typically focused on corporate clients, while women have both institutional and retail clients. Both men and women let their customers buy debts. Their customers, processing companies, paid for the goods about two weeks after receiving fresh tuna, whereas wholesalers or retailers paid for the goods and kept the original debt. Figure 4 presents number of respondents doing business with each type and gender of buyers.

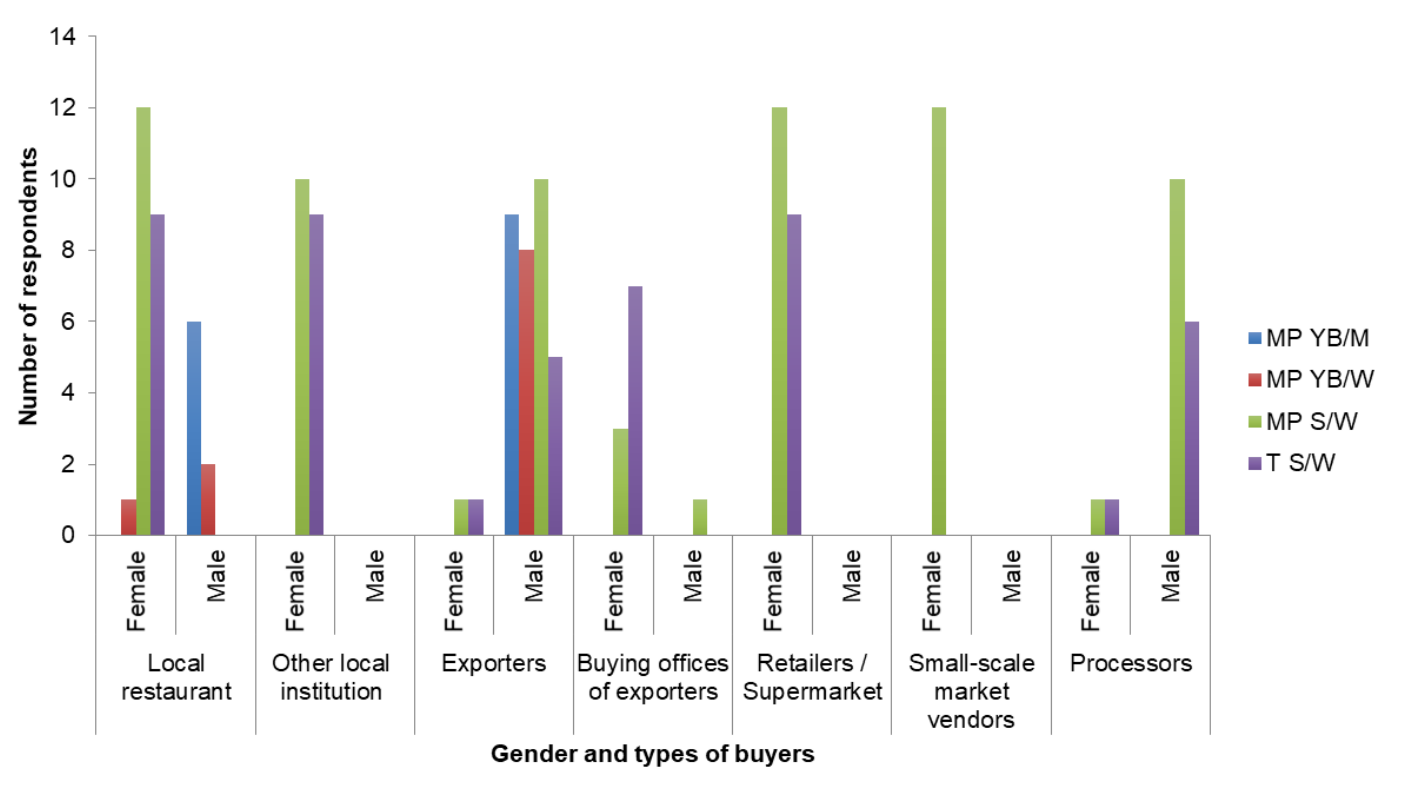

Figure 4. Number of respondents do business with each type and gender of buyers Source: (Sundar Raj, 2020) 
Note. MP YB/M: Middlemen purchasing yellowfin and bigeye tuna, MP YB/W: Middlewomen purchasing yellowfin and bigeye tuna, MP S/W: Middlewomen purchasing skipjack tuna, T S/W: Female traders purchasing skipjack tuna.

\subsubsection{Practices and Participation}

The survey showed that men's and women's main activities in the tuna purchasing stage are based on their physical characteristics. Male laborers typically performed the more physically demanding work such as loading and unloading products, operating the equipment, cleaning and maintaining the facility, taking care of the storage, and transporting tuna to buyers. Also, they carried out other activities, such as quality control and participation in meetings. Meanwhile, female laborers often performed meticulous and careful activities, such as the record of sales and financial transactions, the payment of the bills and salaries, the receiving payments, the processing registration, and legal documents and labeling. They also undertook activities such as weighing, sorting, classifying, packing the products, removing guts and gills, and cooking.

The participation rate of male and female laborers was different according to types of tuna trade. For the skipjack tuna trade, the number of female workers was higher than that of male workers because skipjack tunas have small size and weight so women can participate in tasks such as loading and unloading products, transporting tuna to buyers like men's. Moreover, female laborers were more favored due to their meticulous and hard work, suitable for the purchase of skipjack tuna from 0 am to $8 \mathrm{am}$. Meanwhile, the proportion of male workers was higher than the one of female workers in the purchase of yellowfin and bigeye tuna because of the men's better physical health to meet the demand for heavy jobs. Yellowfin and bigeye tunas have large size and heavy weight that requires laborers to have good health for loading, unloading, and transporting tuna from vessels to trucks, so men are preferred. Figure 5a and Figure 5b depicts business-related administrative tasks and business-related maintenance tasks done by men and women according to the species of tuna traded, respectively.

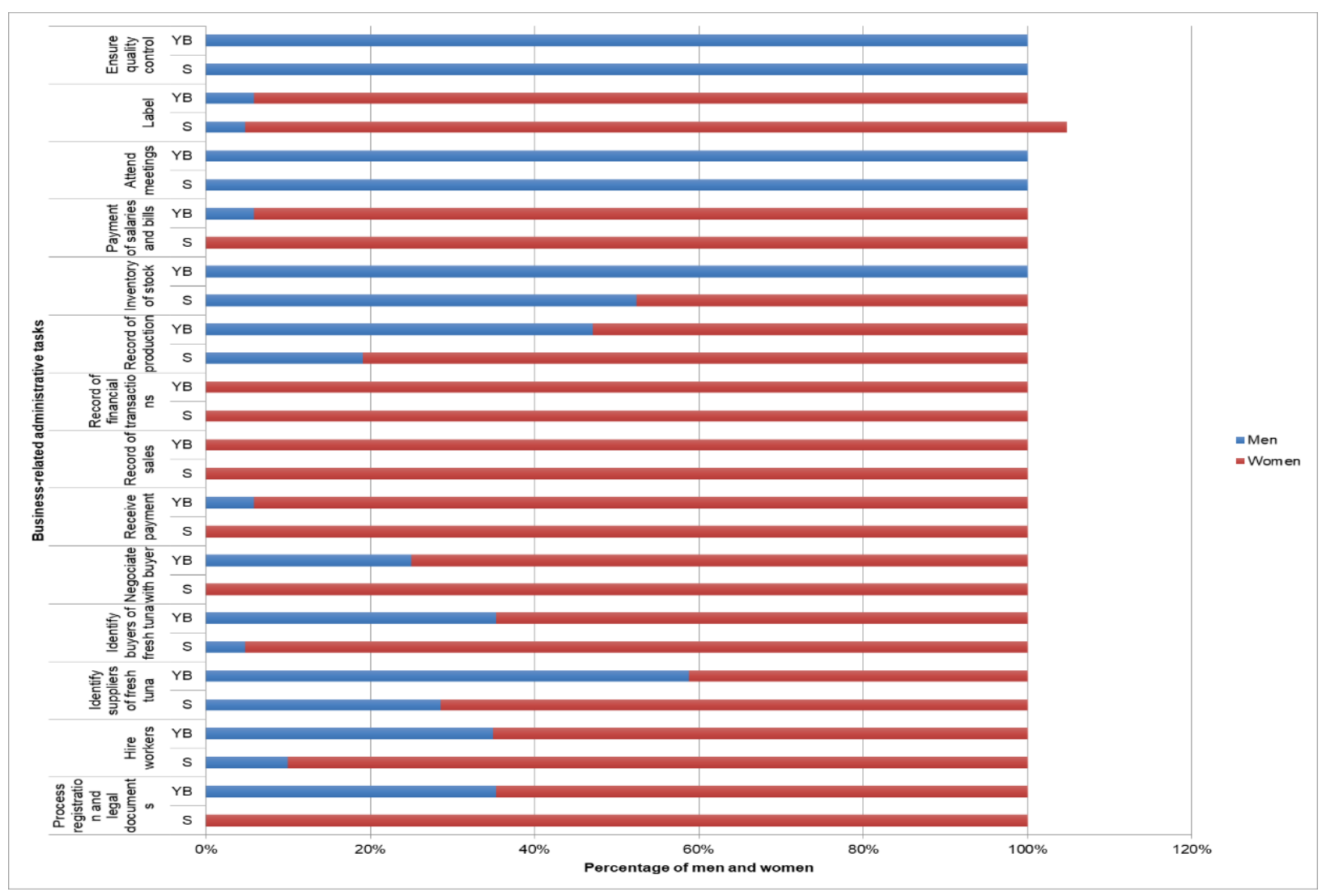

Figure 5a. Business-related administrative tasks done by men and women according to the species of tuna traded Source: (Sundar Raj, 2020) 


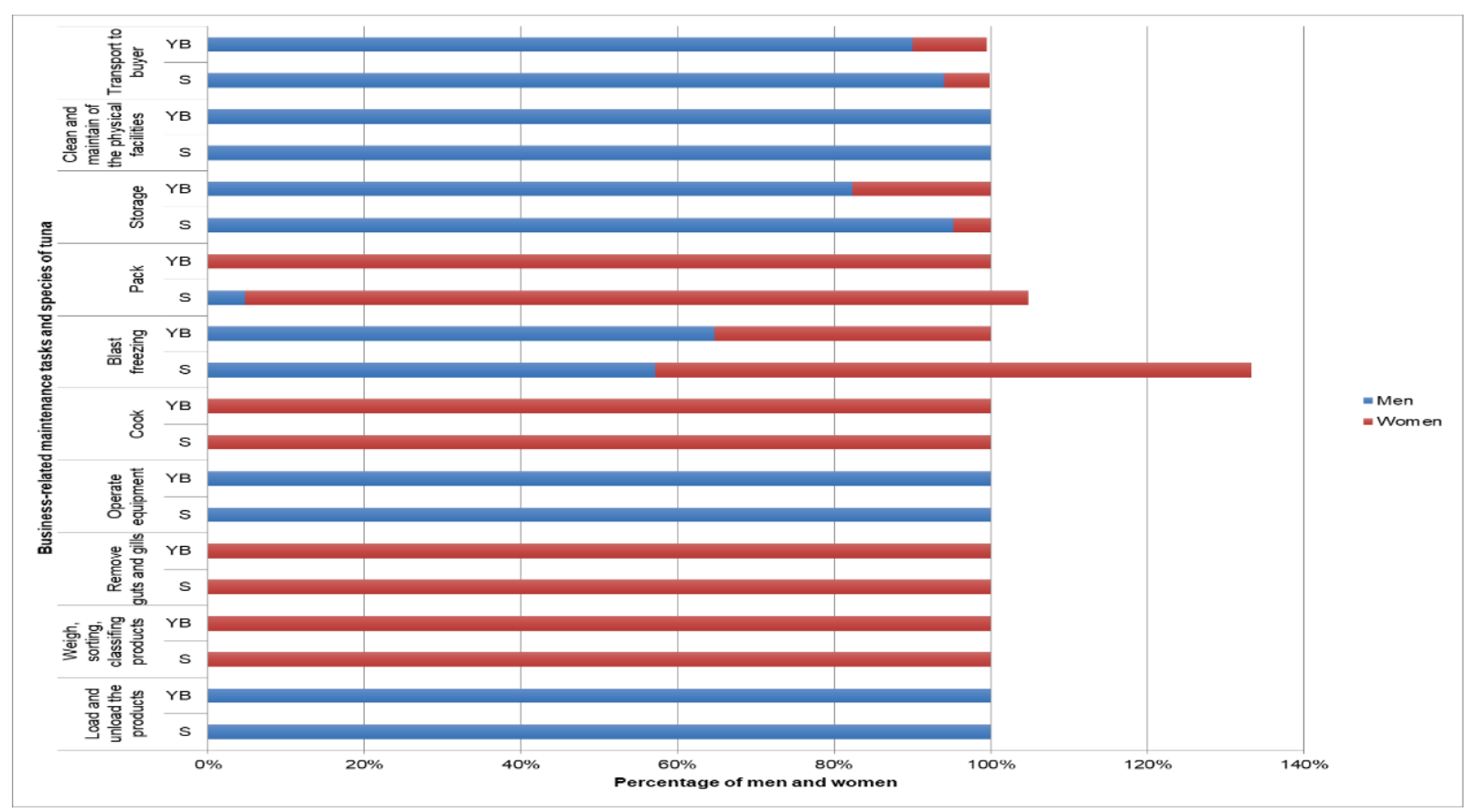

Figure $5 \mathrm{~b}$. Business-related maintenance tasks done by men and women according to the species of tuna traded

Source: (Sundar Raj, 2020)

Note. $\mathrm{S}=$ skipjack tuna, $\mathrm{YB}=$ yellowfin tuna and bigeye tuna

The majority of respondents admitted that their awareness and participation in fishery-related projects/activities were still limited. Most female traders answered that they had never participated in any community activities or association meetings or any coastal management programs. Meanwhile, most middlemen answered that they participated in the meetings related to tuna fisheries, community activities, or coastal management programs as they were invited. On the contrary, most middlewomen responded that they rarely attended any community meetings or fishery related projects/activities, but it was their husbands who did these tasks on their behalf. The majority of middlewomen and female traders focused on their tuna business and immediately returned to their home after finishing the work to take care of their family. Middlewomen in purchasing yellowfin and bigeye tuna sometimes participated in social activities in their communities. Meanwhile, middlewomen and female traders trading skipjack tuna rarely participated in those activities due to their tuna business with this harsh period from 0 am to $8 \mathrm{am}$. They saved all the time after work for compensatory sleeping and taking care of their family. Both middle-persons and female traders likewise admitted that their participation in skills training programs was quite rare.

The participation rate of middle-persons and traders in fishing-related organizations was also minimal. A small percentage of males and females were members of the Vietnam Tuna Association, which included thirty-eight percent middlewomen trading skipjack tuna, and twenty-two percent and thirty percent for middlewomen and middlemen trading yellowfin and bigeye tuna, respectively. However, none of them occupied leadership positions (i.e., president, vice-president, secretary of Vietnam Tuna Association), and all-female traders did not participate in this organization.

\subsubsection{Knowledge, Beliefs, and Perceptions}

\section{- Knowledge}

This study did not reveal significant gender disparities about critical knowledge gaps about tuna and fisheries regulations, however, the comprehensive awareness of these respondents on fisheries policies and laws was quite low. More than half of men (sixty-seven percent) and women (fifty-nine percent) incorrectly answered questions related to current tuna fisheries policies and laws. This evidence found that a critical knowledge gap needs to be explained for the purchasing actors. Provincial managers need to increase the dissemination of the right information on tuna and fisheries regulations to chain actors, especially purchasing agents, due to their impacts on changing fishers' practices and helping processing enterprises operate a better traceability system (USAID, 2020). 
- Skills and abilities

The results showed that women are easier, more skillful and efficient in trading transactions, and pay their debts more often than men. Seventy-eight percent middlemen and one hundred percent middlewomen and female traders believed that "women are more skillful in trading than men.". Also, fifty-five percent middlemen and ninety-two percent middlewomen and female traders stated that "women find it easier to deal with trading business than men.". In addition, sixty-eight percent middlemen and one hundred percent middlewomen and female traders claimed that "women are more efficient in trading than men.". Finally, seventy-eight percent middlemen and one hundred percent middlewomen and female traders believed that "women pay their debts more often than men.". The two reasons for women to have more advantage in the small-scale trade are that first, this activity is not suitable for men since small-scale trading need to be subservient to all other actors (Kusakabe, Sereyvath, Suntornratana, \& Sriputinibondh, 2006) and second, women's natural ability is to avoid conflicts, thus they tend to have better negotiation skills (Weeratunge, Snyder, \& Sze, 2010). Figure 6 depicts the percentage of opinions of men and women on gender-related statements about the tuna trade.

- Enjoyment of the job

The majority of respondents identified themselves as tuna middle-persons and traders with a high degree of job satisfaction. The results presented that there is an insignificant gender difference in the reasons for the tuna trade job's enjoyment. In the purchase of yellowfin and bigeye tuna, both middlemen and middlewomen love their own job due to several reasons, including (i) a good income and a stable and happy life (fifty percent of total respondents); (ii) money to invest in their children's education (thirty percent); (iii) awareness of the importance and the recognition of everyone on their roles in the tuna community in which they feel their freedom, pride, self-development, and better social life as a tuna middle actors (twenty percent). Likewise, most middlewomen purchasing skipjack tuna stated that they love their own job due to the three reasons mentioned above. However, female traders purchasing skipjack tuna love the job because it brings them a good income, a happy and stable life, and their children's chances of schooling. No female traders mentioned that they feel self-developed and proud of their roles in the tuna community. Figure 7 depicts the number of purchasing agents providing the reasons why they enjoy their work by gender and tuna species.

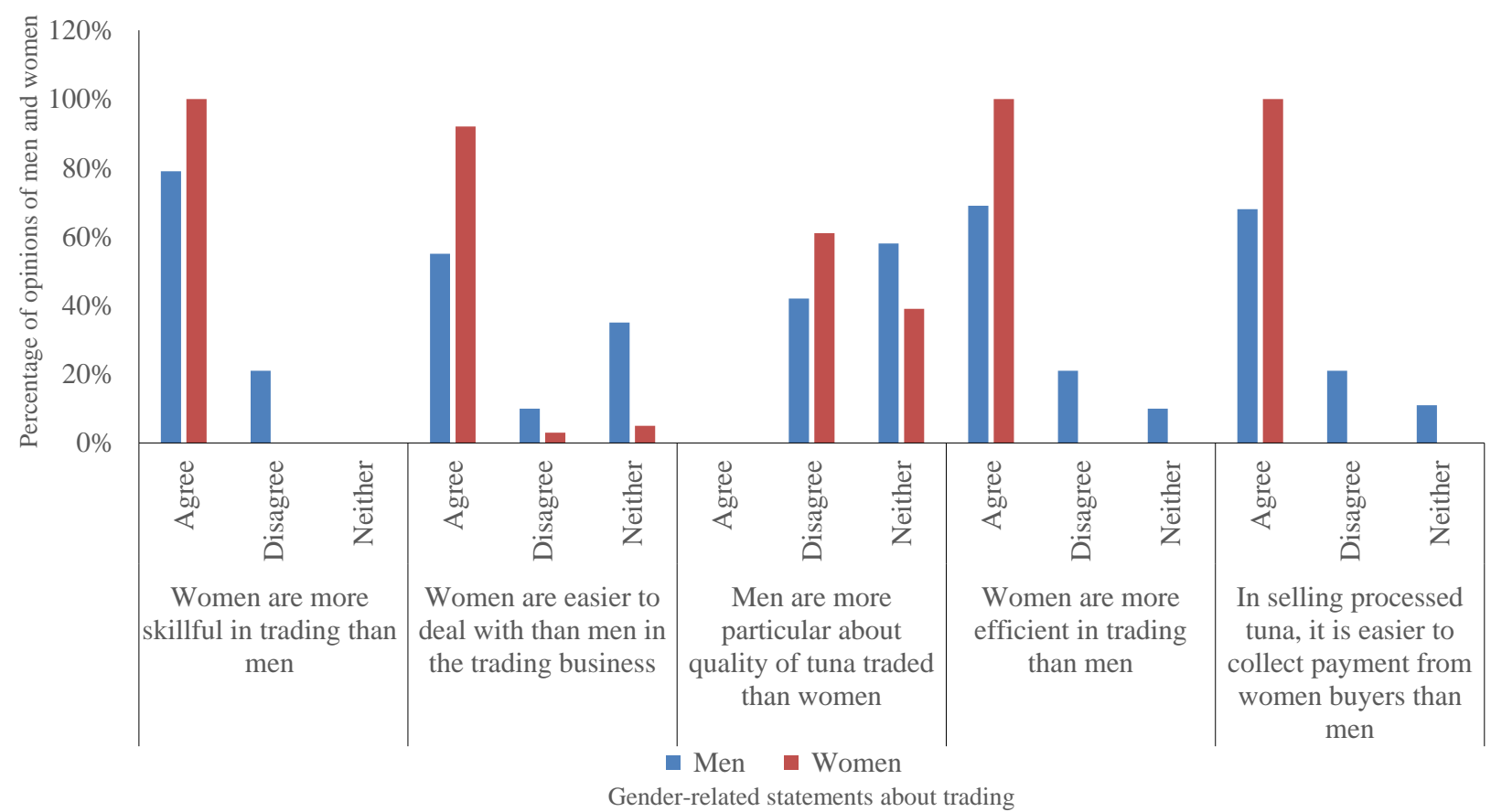

Figure 6. The percentage of opinions of men and women on gender-related statements about the tuna trade Source: (Sundar Raj, 2020) 


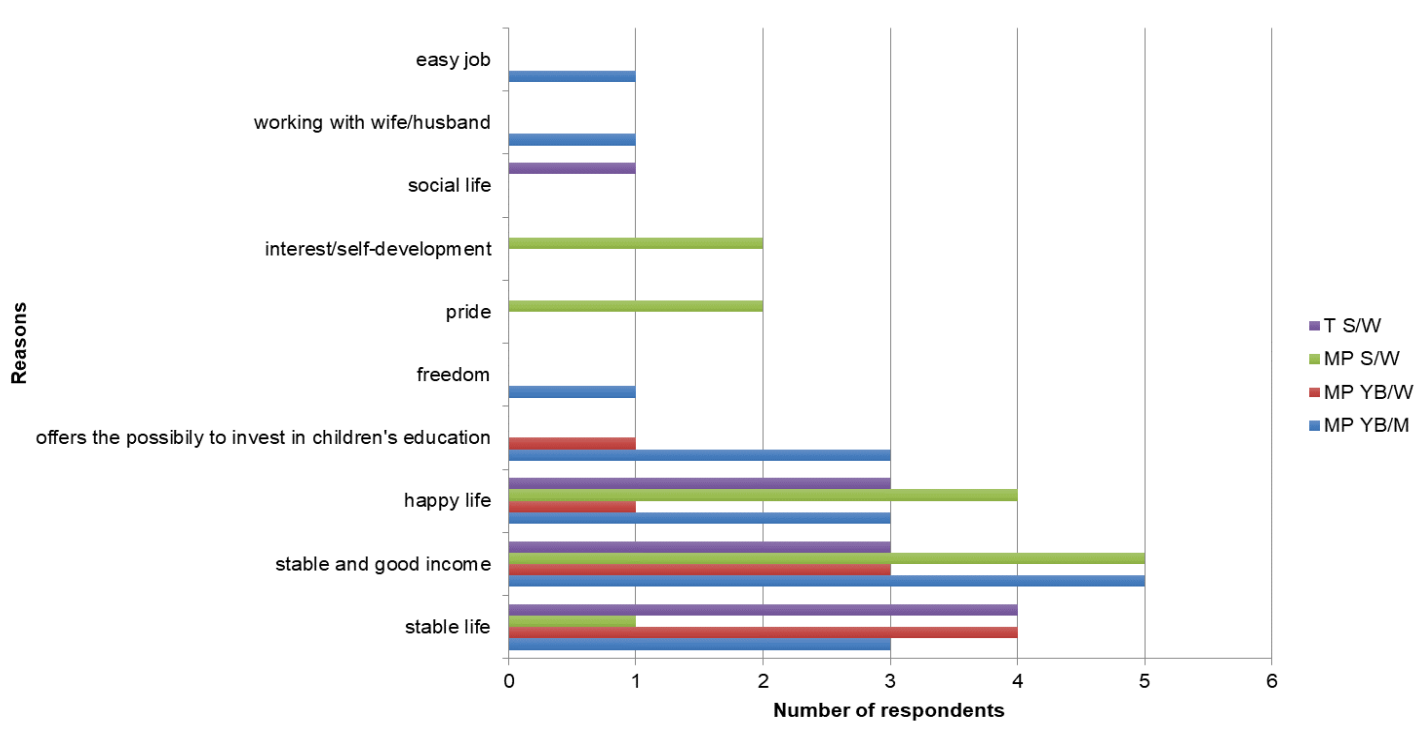

Figure 7. Number of purchasing agents providing the reasons why they enjoy their work by gender and tuna species

Source: (Sundar Raj, 2020)

Note. T S/W: Female traders purchasing skipjack tuna, MP S/W: Middlewomen purchasing skipjack tuna, MP YB/M: Middlemen purchasing yellowfin and bigeye tuna, MP YB/W: Middlewomen purchasing yellowfin and bigeye tuna.

- Hopes and fears

The results showed that most respondents would like to pursue and develop their business for a long time. Middlemen and middlewomen want to have stability and growth in their business to pass it on to their children while no female traders mentioned this capacity. Middle-persons raised fears in purchasing yellowfin tuna and bigeye tuna since their income decreased due to COVID 19 and the resource depletion of yellowfin tuna and bigeye tuna. Figure 8 presents respondents' hopes and fears according to their gender, profession, and tuna species.

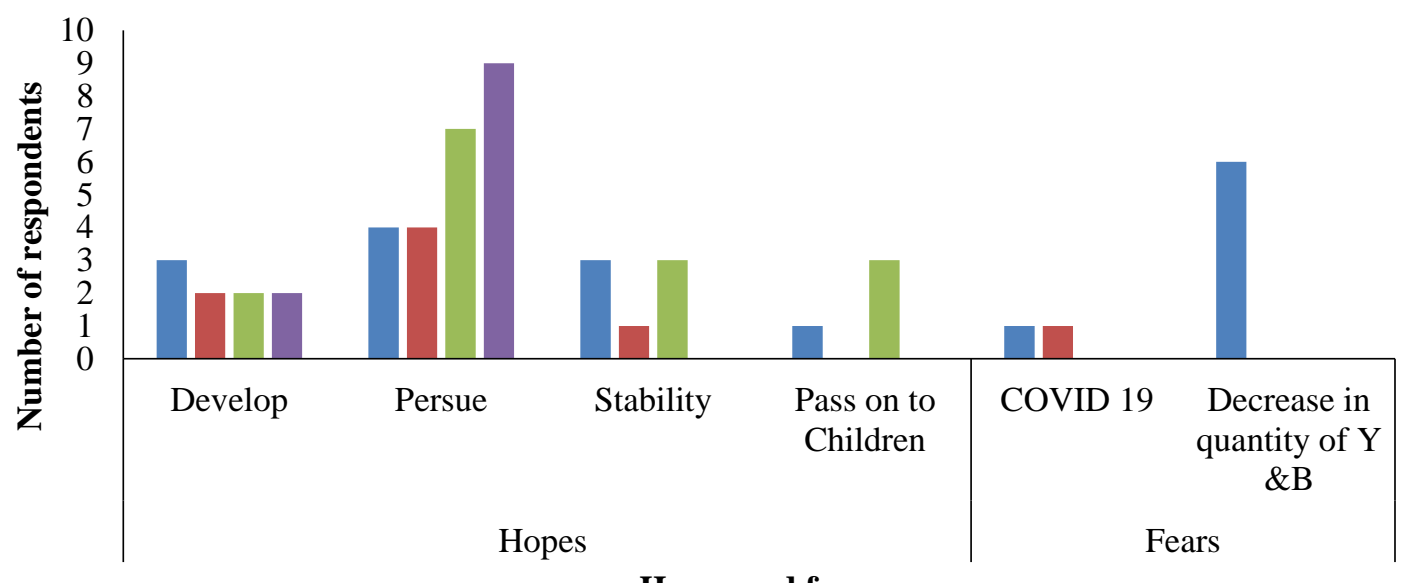

Hopes and fears

$$
\because \mathrm{MP} \mathrm{YB} / \mathrm{M} \backsim \mathrm{MP} \mathrm{YB} / \mathrm{W} \backsim \mathrm{MP} \text { S/W } \approx \mathrm{T} / \mathrm{S}
$$

Figure 8. Respondents'hopes and fears according to their gender, profession and tuna species Source: (Sundar Raj, 2020)

Note. MP S/W: Middle Person purchasing skipjack tuna (middlewomen); T S/W: Trader purchasing skipjack tuna (female trader); MP YB/M: Men (Middlemen) purchasing yellowfin tuna and bigeye tuna; MP YB/W: Women (Middlewomen) purchasing yellowfin tuna and bigeye tuna. 


\subsubsection{Legal Rights and Status}

The results showed that middle-persons and traders easily access to laborers/workers. Specifically, the formers can find the latters within a day whenever trading operations happen. They hired workers by seasons and paid wages according to the traded volume of tuna. A small percentage of employees, such as accountants, purchasing officers, workers at ice facilities, and petrol stations, had long-term contracts. The majority of laborers working on the tuna purchasing stage did not receive accident, life, and health insurances. Also, they were not paid any form of allowances for overtime work. For the skipjack tuna trade, wages were paid equally between men and women due to their similar duties. However, male received higher wages than female in trading yellowfin tuna and bigeye tuna because of the heavier work that men were responsible for. For workers who were pregnant or had small children, they were treated like other workers without priority regimes.

\subsubsection{Power and Decision Making}

\section{- Business-related}

All forty respondents, including thirty women and ten men, were either owners or managers of their tuna businesses. Thirty women, including middlewomen and female traders, were the owners, and claimed that they were the main decision-makers for their businesses. They were responsible for deciding where to buy fresh tunas, whom to sell, where to get financing, and other issues concerning the tuna business, such as giving financial supports for fishers, trading volumes and schedule, and hiring workers. However, most middlewomen were involved in the tuna business with their husbands, who often managed ice facilities and petrol stations. These middlewomen reported that they sometimes consulted their spouses in significant business decisions due to the men's understanding and position as the heads of households. Out of the ten middlemen, eight only managed general businesses, such as working with processors, managing finance, etc., whereas their wives handled tuna procurement, laborers, and other work at the fishing port on behalf of their husbands. For each couple, the husband and the wife consulted with each other to make common decisions on business issues. The remaining two middlemen were business owners and managed all tuna business activities, while their wives were housewives and incompletely understand their husbands' businesses. These husbands were not obliged to consult their spouses on matters related to their businesses but found no harm informing the wives about the business status. The husbands were also responsible for transferring the business earnings to their wives, who were in charge of managing the household budget.

\section{- Household-related}

Regarding household decision issues, both male and female interviewees agreed that the mother decided on food purchase and preparation, budgeting household income while the father gave decisions on leisure activities, health activities, family rules, and community activities. Both father and mother discussed and made joint decisions on their children's education. Respondents answered that their families follow the patrilineal regime in which the father is the head of the family. In particular, both husband and wife have their opinions related to family issues, but the final decisions are made by men. Women are responsible for taking care of children, managing housework and family budget. They are money-keepers and pay for small household items, while their husbands decide on big expenses.

\section{- Community management}

The survey showed that sixty-three percent men and fifty-four percent women sometimes participated in community activities. Most respondents had never participated in training programs, public hearings, and coastal resources management programs. Many middlewomen admitted that they did not have free time to join these activities since they have to save their time for doing tuna business and taking care of their family. Meanwhile, middlemen answered that they would not like to spend much time attending those activities because they found them not useful for their tuna business. Thus, none of the respondents were either a Vietnam Tuna Association president, or a committee member, or a marine resource manager at local levels.

\subsubsection{Time and Space}

\section{- Working time}

For the yellowfin and bigeye tuna trade, the peak period for purchasing tuna or the main harvest season of tuna occurs from November to May, while the rest of the year is the low period. Fishers use the handline/longline method combining with light to catch tuna, so they go off-shore when moon set and return to the fishing port when moon rise. Thus, the purchase of yellowfin and bigeye tuna only takes place from the seventh to the twenty-third of every month according to the lunar calendar. During the peak period, middlemen had higher average number of working hours than middlewomen, at $16.5 \pm 0.7$ hours/per day and $14.8 \pm 1.8$ hours/per day, 
respectively, but the difference is insignificant (Dunn, $\mathrm{p}=1$ ). During the low period, the average number of working hours of middlemen were significantly lower than that of middlewomen at $4.8 \pm 3.16$ hours/per day and $6.0 \pm 2.14$ hours/per day, respectively (Dunn, $p=0.03$ ). A large amount of yellowfin and bigeye tuna is mainly sold to processing companies, so the daily working time of middle-persons is from $7 \mathrm{am}$ to $5 \mathrm{pm}$.

The skipjack tuna trade takes place all year round, and its peak period lasts from December to May. Fishers use purse seine and gillnet methods to catch tuna, and the tuna fishing vessels landed at the fishing port every day. During the peak period, the middlewomen and female traders had an average number of working hours of about sixteen hours per day at the fishing port, while that during the low period was eight hours per day. Compared to the trade of yellowfin and bigeye tuna, the skipjack tuna trade requires a longer working time and a harder schedule due to its regular working time from 0 am to 8 am every day.

- Spare time

Regarding spare time, the activities of men and women were completely different. Ninety-six percent women, who were married, reported that they did not have spare time. They had to take care of their children and family after finishing their work at the fishing ports. Only one woman, who was single, had free-time after work. Meanwhile, eighty-nine percent middlemen said that they spent spare time for activities such as drinking beer or having coffee with their friends and talking to partners to expand their relationships. Only eleven percent men answered that they did housework with their wives and educate their children after work. We emphasize here that the middlewomen and female traders trading skipjack tuna have to work from midnights to early mornings, so they often sleep and take care of their families during daytime. Thus, most of them do not have spare time for their leisure activities.

In addition, Vietnamese culture expects women to be mainly responsible for childcare and housework, while middlewomen and female traders do not allow this cultural expectation to limit the time and labor that they commit to their business. They would like to do well in both of the productive and the reproductive roles. Most women presented at the fishing ports just in time for the tuna purchase and immediately returned home after finishing their work for doing their duties as a daughter-in-law, a wife, and a mom. A large amount of time that women spend on their productive and reproductive activities had negative impacts on other areas of their lives, for example, they had less time for leisure, sleep and rest.

The overwhelming majority of middlewomen and female traders were not interested in any fisheries activities in their community. All female traders have never participated in any of these activities, while a few middlewomen were aware of them and sometimes participated in. The productive and reproductive responsibilities had already taken up spare time of those women, making them not have enough time to participate in community programs actively.

\section{- Distance}

The middle-persons and traders were local people and had close relationships with tuna fishers. Most respondents reported that their house is very close to the fishing port. The average distance between their house and the fishing port by gender is $4.72 \pm 2.07$ kilometers for women and $5.67 \pm 2.0$ kilometers for men, which is not significant (Wilcoxon, $\mathrm{p}=0.151$ ). The majority of the middle-actors went to the fishing ports by motorbike; only one middleman and one middlewoman traveled by car to get to the port. Most female partners said that doing tuna business closed to their home helps them fulfill both productive and reproductive roles, while male partners answered that trading tuna in the fishing port was very convenient for their business due to the availability of good relationships with fishers and processors.

\section{Discussions and Conclusion}

\subsection{Discussions}

This study provides valid evidences for gender analysis in the tuna fisheries community by identifying the gender differences between men and women as purchasing actors on the tuna value chain in Binh Dinh province. The gender disparities between men and women were shown in productive, reproductive, and community roles based on USAID's six gender dimensions to assess gender differentials in access to resources; beliefs, knowledge and perception; practices and participation; time and space; legal rights and status; and power and decision-making. Issues on gender equity, women's empowerment, and sustainable tuna management will be presented in Sections 5.1.1 and 5.1.2. Several recommendations will be proposed in Section 5.1.3 to improve these issues. 


\subsubsection{Issues on Gender Equity and Empowerment}

- Responsibilities in tuna business management and household chores limit women's exposure to the community life. The majority of middlewomen and female traders do not have enough free time to involve in fisheries organizations and related activities in their communities. Failure to participate in these activities results in women's deficiency in organizational skills and positive relationships with other actors in the tuna value chain.

- Due to being kept busy with their productive and reproductive activities, most women seem to be unable to spend time on their leisure and sleep/rest. Particularly, in addition to upbringing children and doing household chore, middlewomen and traders are also required to manage the tuna business at the fishing ports while the average working time is equal to or even higher than men's. Therefore, women's lack of free time reduces their opportunities to establish good relationships to have broader and more profitable markets.

- Women's reproductive role, which is unpaid, makes it difficult for middlewomen and female traders to accumulate capital and experience in the startup stage. In particular, women did not receive any incentives/benefits during pregnancy and child rearing, so they depended entirely on their husbands during this period.

- The low educational attainment of middlewomen and female traders can badly/ negatively result in the efficiency of their tuna business. Also, owing to less chance for training programs on business skills and tuna fisheries management, many women lack necessary management skills for their business.

- Most middlewomen and female traders play less important role in decision-making even though they are business owners. Particularly, in order to make any significant decisions on work issues, they have to consult with their spouses who are considered the family head.

- Women are constrained to traditional norms and values in society to participate in the decision-making process actively. Some stereotypes in terms of productive, reproductive and social roles are listed below:

Gender disparity in work management and administration. In all tuna businesses, women are in charge of managing tuna procurement and managing other tasks at the fishing ports. As regards men, middlemen are responsible for managing ice factories and petrol stations and doing bank transactions.

$>$ Gender disparity in the allocation of activities in the purchasing phase. Most of the male laborers are involved in physically demanding jobs while female laborers' major responsibilities deal with administrative tasks.

$>$ Gender disparity in family life. Middle-women and female traders are mainly responsible for upbringing children and doing housework, whereas men only get involved if they feel their willingness.

$>$ Gender disparity in decision-making in family. Due to patrilineal culture in which man is the head of the family, the final decisions are made by the husband even though women are involved in discussion on family related issues.

$>$ Gender disparity in professional community management activities. Women had a less critical voice than men in these community activities. In particular, most middlewomen and female traders take secondary role in tuna fisheries or community organizations while men often have the final say in community activities and fisheries-related organizations/projects.

Despite being constrained to traditional norms and values, middlewomen and female traders take the dominant role in the tuna business in terms of productivity and financial investment for tuna vessels. Therefore, the tuna trade has brought women a certain degree of empowerment in which middlewomen and female traders could asserted their positions in the tuna business.

\subsubsection{Issues on Sustainable Fisheries Management}

- The knowledge gap of the purchasing actors on tuna and fishery regulations is quite low. This, as a result, has triggered their misunderstanding in laws, regulations, and current tuna fisheries policies.

- The limited participation of purchasing actors, especially middlewomen and female traders, in fisheries-related activities/projects in the community mitigates the decisive voice of women in fisheries organizations and community projects.

- The purchasing actors suffer low income and unsustainable livelihoods due to resource depletion of yellowfin and bigeye tuna. Consequently, purchasing agents have to look for other ways to make their living, for example, purchasing other seafood or investing in other businesses such as hotel services, restaurants, etc. 


\subsubsection{Recommendations}

The study has identified significant issues such as gender equity, women's empowerment, sustainable tuna fisheries management issues, the following intervention policies are recommended.

Regarding gender equity and women's empowerment, first of all, gender-responsive strategies should place the emphasis on women's important role in housework, unpaid work. Secondly, it is necessary to establish tuna trading management board at the fishing ports to easily gather information of needs, problems, and interests of middle-persons and traders. All of these activities should be supported by the local authority and operate as a platform for men and women to discuss common or different tuna trade issues as well as share knowledge and information at the fishing ports to prevent wasting participants' time, especially women.

As regards women's roles in tuna business community and production, local authorities need to have policies on economic, social, and educational supports for tuna middle-persons and traders in general, and for women in particular. Specifically, women, especially female traders, should be provided access to savings, credit, micro-finance services, so that they can have opportunities for expanding their business. In addition, alternative job opportunities must be offered in low seasons, especially for female workers. Besides, training courses on tuna business and management skills should be conducted/ organized at the fishing port during the low periods so that all purchasing actors, especially women, can fully participate in them. Finally, fishing port facilities for the community's well-being in general and women's benefits of using the facilities in particular must be improved.

In terms of sustainable tuna fisheries management, local managers should increase the dissemination of information on tuna fisheries and fisheries policies during the low periods. The aim is to increase the purchasing actors' awareness, to ensure the sustainability of tuna business activities, and to improve sustainable tuna fisheries management with the ultimate goal of enhancing the competitiveness of the tuna value chain. Besides, local managers should have policies to support purchasing actors, especially for laborers in the yellowfin and bigeye tuna trade, to look for alternative ways of earning money to compensate for the resource depletion.

\subsection{Conclusion}

This paper presents gender analysis at the tuna value chain's purchasing stage in Binh Dinh province in 2020. We used gender analysis tools such as Harvard, Moser, , and USAID's six gender dimensions to identify the gender disparities between men and women as middle-persons and traders in productive, reproductive, and community roles. This study helps to identify significant issues such as gender equity, women's empowerment, sustainable tuna fisheries management issues, and suggests intervention policies.

\section{Acknowledgments}

The authors of this paper would like to thank the National Science and Technology Research Project of Developing Feasible and Comprehensive Policies for Sustainable Fisheries Development in Vietnam, Project code: KC.09.24/16-20; 2018-2020, for their data providing, technical guidances, and necessary supports to compile this paper.

\section{References}

Barclay, K., Payne, A. M., Mauli, S., \& Krushelnytska, O. (2015). Toward Gender-Quitable Fisheries Management in Solomon Islands. Washington, D.C.: World Bank Group. Report number: 98279. Retrieved from http://documents.worldbank.org/curated/en/467721468187800125/Toward-gender-equitable-fisheriesmanagement-in-Solomon-Islands

Bennett, E. (2005). Gender, Fisheries and Development. Marine Policy, 29(5), 451-459. https://doi.org/10.1016/j.marpol.2004.07.003

Binh Dinh Province People's Committee. (2018). Binh Dinh-Potential and Investment Opportunities. Retrieved from https://binhdinh.gov.vn/inetcloud/portal/en/page/listdetail.ivt?intl=en\&id=5660fbdc9ec5796ea6f7d683

Calhoun, S., Conway, F., \& Russell, S. (2016). Acknowledging the Voice of Women: Implications for Fisheries. Management and Policy. Marine Policy, 74, 292-299. https://doi.org/10.1016/j.marpol.2016.04.033

Chapman, M. (1987). Women fishing in Oceania. Human Ecology, 15(3), 267-288. https://doi.org/10.1007/BF00888026

Choo, P. S., Nowak, B. S., Kusakabe, K., \& Williams, M. J. (2008). Guest Editorial: Gender and Fisheries. Development, 51(2), 176-179. https://doi.org/10.1057/dev.2008.1

Diamond, N. K., Squillante, L., \& Hale, L. Z. (2003). Cross Currents Navigating Gender and Population 
Linkages for Integrated Coastal Management. Marine Policy, 27(4), $325-331$. https://doi.org/10.1016/S0308-597X(03)00044-7

EIGE (European Institute for Gender Equality). (2015). Gender Analysis. Retrieved from https://eige.europa.eu/gender-mainstreaming/methods-tools/gender-analysis

FAO. (2011). Gender and Agricultural Value Chains- A Review of Current Knowledge and Practice and their policy implications, by Christopher Coles and Jonathan Mitchell. ESA Working Paper No. 11-05. Retrieved from http://www.fao.org/3/a-am310e.pdf

FAO. (2011). Gender Inequality, Risk and Vulnerability in the Rural Economy: Re-focusing the Public Works Agenda to Take Account of Economic and Social Risks, by Rebecca Holmes and Nicola Jones. ESA Working Paper No. 11-13. Retrieved from http://www.fao.org/3/a-am318e.pdf

FAO. (2015). A Review of Women's Access to Fish in Small-Scale Fisheries, by A. Lentisco and R. U. Lee. Fisheries and Aquaculture Circular, (1098), Rome, Italy. Retrieved from http://www.fao.org/3/a-i4884e.pdf

Fro“cklin, S., Castro, M. D. L. T., Lindstro“m, L., \& Jiddawi, N. S. (2013). Fish Traders as Key Actors in Fisheries: Gender and Adaptive Management. AMBIO, 42, 951-962. https://doi.org/10.1007/s13280-013-0451-1

Harper, S., Grubb, C., Stiles, M., \& Sumaila, R. (2017). Contributions by Women to Fisheries Economies: Insights from Five Maritime Countries. Coastal Management, 45(2), 91-106. https://doi.org/10.1080/08920753.2017.1278143

Harper, S., Zeller, D., Hauzer, M., Pauly, D., \& Sumaila, U. R. (2013). Women and Fisheries: Contribution to Food Security and Local Economies. Marine Policy, 39, 56-63. https://doi.org/10.1016/j.marpol.2012.10.018

Hauzer, M., Dearden, P., \& Murray, G. (2013). The Fisherwomen of Ngazidja Island, Comoros: Fisheries Livelihoods, Impacts, and Implications for Management. Fisheries Research, 140, 28-35. https://doi.org/10.1016/j.fishres.2012.12.001

Hillenbrand, E., Lakzadeh, S., \& Talukder, A. (2014). Using the Social Relations Approach to Capture Complexity in Women's Empowerment: Using Gender Analysis in the Fish on Farms Project in Cambodia. Gender and Development, 22(2). https://doi.org/10.1080/13552074.2014.9209921

Kabeer, N. (1995). Reversed Realities: Gender Hierarchies in Development Thought. Contemporary Sociology, 24(5). https://doi.org/10.2307/2077366

Kabeer, N. (1996). Agency, Well-being \& Inequality: Reflections on the Gender Dimensions of Poverty IDS. Bulletin, 27(1), 11-21. https://doi.org/10.1111/j.1759-5436.1996.mp27001002.x

Kabeer, N. (1999). Resources, Agency, Achievements: Reflections on the Measurement of Women's Empowerment. Development and Change, 30(3), 435-464. https://doi.org/ 10.1111/1467-7660.00125

Koralagama, D. K., Gupta, J., \& Pouw, N. (2017). Inclusive Development from a Gender Perspective in Small Scale Fisheries. Current Opinion in Environmental Sustainability, 24, 1-6. https://doi.org/10.1016/j.cosust.2016.09.002

Kruijssen, F., Albert, J., Morgan, M., Boso, D., Siota, F., Sibiti, S., \& Schwarz, A. J. (2013). Livelihoods, Markets, and Gender Roles in Solomon Islands: Case Studies from Western and Isabel Provinces. CGIAR Research Program on Aquatic Agricultural Systems. Penang Malaysia. Project Report: AAS-2013-22. Retrieved from https://www.worldfishcenter.org/content/livelihoods-markets-and-gender-roles-solomon-isla nds-case-studies-western-and-isabel-0

Kusakabe, K., Sereyvath, P., Suntornratana, U., \& Sriputinibondh, N. (2006). Women in Fish Border Trade: The Case of Fish Trade between Cambodia and Thailand. Retrieved from http://pubs.iclarm.net/Pubs/Gender\& FisheriesDec04/11_GD.pdf

March, C., Smyth, I., \& Mukhopadhyay, M. (1999). A Guide to Gender Analysis Frameworks. Oxfam GB. Retrieved from https://www.ndi.org/sites/default/files/Guide\%20to\%20Gender\%20Analysis\%20Frame works.pdf

Mcgregor, J. A., \& Camfield, W. (2009). Needs, Wants and Goals: Wellbeing, Quality of Life and Public Policy. Applied Research in Quality of Life, 4(2), 135-154. https://doi.org/ 10.1007/s11482-009-9069-7

Medard, M. (2012). Relations between People, Relations about Things: Gendered Investment and the Case of the 
Lake Victoria Fishery, Tanzania. Signs Journal of Women in Culture and Society, 37(3), 555-566. https://doi.org/10.1086/662704

Moser, C. O. (1993). Gender Planning and Development: Theory, Practice, and Training. London: Routledge. Retrieved from https://www.routledge.com/Gender-Planning-and-Development-Theory-Practice-andTraining/Moser/p/book/9780415056212

O’Neill, E. D., Asare, N. K., \& Aheto, D. W. (2018). Socioeconomic Dynamics of the Ghanaian Tuna Industry: A Value-Chain Approach to Understanding Aspects of Global Fisheries. African Journal of Marine Science 40(3), 303-313. https://doi.org/10.2989/1814232X.2018.1513866

Overa, R. (1993). Wives and Traders: Women's Careers in Ghanian Canoe Fisheries. MAST, 6(1/2), 110-135.

Oxfam. (2016). Identifying Gender Inequalities and Possibilities for Change in Shrimp Value Chains in Montreal Indonesia and Vietnam. Retrieved from https://asia.oxfam.org/policy-paper/identifying-gender-inequalitiesand-possibilities-change-shrimp-value-chains-indonesia

Silva, D. D. A. M. D. (2011). Faces of women in global fishery value chains-Female involvement, impact and importance in the fisheries of developed and developing countries. FAO. Retrieved from http://www.fao.org/valuechaininsmallscalefisheries/projectreports/en/

Sundar Raj, R. (2020). Gender Analysis in the Purchasing Node in the Tuna Value Chain in the Central Provinces of Vietnam. Master thesis in bioengingeering: Agronomic sciences, specialized focus. Gembloux Agro-Bio Tech (GxABT). University of Liege, Gembloux, Belgium. Retrieved from https://matheo.uliege.be/handle/2268.2/10255

Thorpe, A., Pouw, N., Baio, A., Sandi, R., Ndomahina, E., \& Lebbie, T. (2014). "Fishing Na Everybody Business": Women's Work and Gender Relations in Sierra Leone's Fisheries. Feminist Economics, 20(3), 53-77. https://doi.org/10.1080/13545701.2014.895403

Thu, N. D. H., Quyen, C. L., Hang, L. T. M., Tran, N. T. T., \& Lebailly, P. (2020). Social Value Chain Analysis: The Case of Tuna Value Chain in Three South Central Provinces of Vietnam. Asian Social Science, 16(8). https://doi.org/10.5539/ass.v16n8p43

Tuara, P. N. (2006). Gender Issues in the Pacific Islands Tuna Industry: June 2006. Noumea, New Caledonia: Secretariat of the Pacific Community (SPC). 51 p. Retrieved from https://pacificdata.org/data/dataset/oaiwww-spc-int-7e69b08d-fb2e-4f11-8709-14c3a40bdf7f

USAID (2012). Toward Gender Equality in Europe and Eurasia: A Toolkit for Analysis, USA. Retrieved from https://www.jbsinternational.com/sites/default/files/USAID_Gender_Equality_Toolkit_Final.pdf

USAID (2018). Gender Considerations in Tuna Fisheries. 15th Infofish World Tuna Conference: Tuna 2018. Bangkok, Thailand. Retrieved from http://www.tuna.infofish.org/images/Presentation/Day3/44.\%20Arle ne\%20Gender-Tuna-ANS-3.pdf

USAID (2020). Tuna Value Chain Analysis for Binh Dinh Province, Vietnam. Retrieved from https://www. seafdec-oceanspartnership.org/resource/tuna-value-chain-analysis-for-binh-dinh-province-vietnam/

Veliu, A., Gessese, N., Ragasa, C., \& Okali, C. (2009). Gender Analysis of Aquaculture Value Chain in Northeast Vietnam and Nigeria. World Bank. https://doi.org/10.1596/28276

Vervaele, K. (2014). Flemish Fishermen's Wives: Their Lives and Roles in Fisheries. Social Issues in Sustainable Fisheries Management, 201-213. https://doi.org/10.1007/978-94-007-7911-2_11

Walker, B. L. E. (2001). Sisterhood and Seine-Nets: Engendering Development and Conservation in Ghana's Marine Fishery. The Professional Geographer, 53(2). https://doi.org/10.1111/0033-0124.00277

Walker, B. L. E. (2002). Engendering Ghana's Seascape: Fanti Fishtraders and Marine Property in Colonial History. Society and Natural Resources, 15(5), 389-407. https://doi.org/10.1080/08941920252866765

Weeratunge, N., \& Snyder, K. (2009). Gleaner, Fisher, Trader, Processor- Understanding Gendered Employment in the Fisheries and Aquaculture Sector. FAO-IFAD-ILO Workshop on Gaps, trends and current research in gender dimensions of agricultural and rural employment: differentiated pathways out of poverty. At: Rome, Italy. Retrieved from https://www.researchgate.net/publication/237301068_Gleaner_fisher_trader_proce ssor_understanding_gendered_employment_in_the_fisheries_and_aquaculture_sector

Weeratunge, N., Béné, C., Siriwardane, R., Charles, A., Johnson, D., Allison, E., H., Nayak, P., K., \& Badjeck, M. C. (2013). Small-Scale Fisheries through the Wellbeing Lens. Fish and Fisheries, 15(2). 
https://doi.org/10.1111/faf.12016

Weeratunge, N., Chiuta, T. M., Choudhury, A., Ferrer, A., Hüsken, S. M. C., Kura, Y., ... Kantor, P. (2012). Transforming Aquatic Agricultural Systems Towards Gender Equality: A Five Country Review. Aquatic Agricultural System AAS-2012-21. https://doi.org/10.13140/RG.2.2.10436.58243

Weeratunge, N., Snyder, K., A., \& Sze, C. P. (2010). Gleaner, Fisher, Trader, Processor: Understanding Gendered Employment in Fisheries and Aquaculture Fish and Fisheries. Fish and Fisheries, 11(4). https://doi.org/10.1111/j.1467-2979.2010.00368.x

Wessels, P. (2017). The Roles of Women in Maldivian One-by-One Tuna Supply Chains: A Scoping Study. Dalhousie University, International Pole \& Line Foundation. Retrieved from http://ipnlf.org/resources/ipnlfdocuments/document/the-roles-of-women-in-maldivian-one-by-one-tuna-supply-chains-a-scoping-study

Williams, M. J. (2008). Why look at Fisheries through a Gender Lens? Development, 51(2), 180-185. https://doi.org/10.1057/dev.2008.2

\section{Copyrights}

Copyright for this article is retained by the author(s), with first publication rights granted to the journal.

This is an open-access article distributed under the terms and conditions of the Creative Commons Attribution license (http://creativecommons.org/licenses/by/4.0/). 